\title{
PENGARUH PEMBERIAN PUPUK KOTORAN KAMBING DAN ATONIK TERHADAP PERTUMBUHAN SETEK DAUN MAHKOTA NENAS (Ananas comusus L. Merr) KUALU PADA MEDIA GAMBUT
}

\author{
Goat Manure Fertilizer Effect on Growth and Atonik Leaf Cuttings Crown \\ Pineapple (Ananas comusus L. Merr) Kualu on Media Peat
}

\author{
Mardaleni \\ Program studi Agroteknologi Fakultas Pertanian Universitas Islam Riau \\ Jl. Kaharuddin Nasutiaon KM 11 No. 113 MarpoyanPekanbaru \\ Email: mardaleniuir@agr.uir.ac.id \\ [Diterima: Juli 2019; Disetujui: Agustus 2019]
}

\begin{abstract}
ABSTRAK
The Kualu pineapple propagation technique uses crown bud cuttings which is made as a pineapple plant propagation material for peat media that is added with goat manure and several concentrations of Atonic. The aim is to obtain an effective source of cutting material for the procurement of Kualu pineapple seedlings cultivated on peat soil. This research used a Completely Randomized Design (CRD) factorial with two factors. First factor was the dose of goat manure at levels $0,10,20$, and $30 \mathrm{~g} /$ polybag dan second factor was various atonic concentrations at levels $0,2,4$, and $6 \mathrm{ml} / \mathrm{L}$. The data were statistically analyzed and further tested for honest real difference (BNJ) at the $5 \%$ level. The results obtained from the interaction of the two treatment factors were significantly different to the time of shoot emergence and the percentage of shoot life. There was no significant difference in seedling height and number of leaves, as well as the main effect of each treatment. Crown shoot cuttings planted on peat media added $20 \mathrm{~g} /$ polybag of goat manure and $4 \mathrm{ml} / \mathrm{l}$ Atonic obtained a better source of cutting material to be used as a source of seeds than others. The success of obtaining seeds from crown leaf cuttings sources through this research has answered that crown leaf cuttings have potential and great opportunity to be developed.
\end{abstract}

Keywords: Pineapple-Kualu, Cuttings, Crown-shoots, Atonic, Peat.

\begin{abstract}
ABSTRAK
Teknik perbanyakan nenas Kualu menggunakan setek mata tunas mahkota, dijadikan sebagai bahan perbanyakan tanaman nenas pada media gambut yang ditambah pupuk kotoran kambing dan beberapa konsentrasi Atonik. Tujuannya untuk mendapatkan sumber bahan setek yang efektif dalam pengadaan bibit nenas Kualu yang dibudidayakan pada tanah gambut. Rancangan yang digunakan adalah Rancangan Acak Lengkap (RAL) faktorial, faktor pertama adalah dosis pupuk kotoran kambing pada taraf 0, 10, 20 dan 30 g/polybag. Faktor kedua adalah berbagai konsentrasi atonik pada taraf 0, 2, 4 dan $6 \mathrm{ml} / \mathrm{l}$. Data dianalisis secara statistik dan diuji lanjut beda nyata jujur (BNJ) pada taraf 5\%. Hasil yang diperoleh interaksi dari kedua faktor perlakuan berbeda nyata terhadap saat muncul tunas dan persentase hidup tunas. Tidak berbeda nyata terhadap tinggi bibit dan jumlah daun, demikian juga pengaru utama masing-masing perlakuan. Setek tunas mahkota yang ditanam pada media gambut yang ditambahkan $20 \mathrm{~g}$ /polybag pupuk kotoran kambing dan 4ml/1 Atonik didapat sumber bahan setek yang lebih baik untuk dijadikan sumber bibit berbanding yang lainnya. Keberhasilan memperoleh bibit dari sumber setek daun mahkota melalui penelitian ini sudah terjawab bahwa setek daun mahkota memiliki potensi dan berpeluang besar untuk dikembangkan.
\end{abstract}

Kata kunci : Nenas-Kualu, Setek, Tunas-mahkota, Atonik, Gambut

\section{PENDAHULUAN}

Tanaman nenas merupakan komoditas andalan ekspor buah domestik, Indonesia merupakan eksportir nenas olahan nomor tiga didunia, setelah Filipina dan Thailand
(Harianto dkk 1996). Peluang ekspor juga terbuka untuk produk buah segar. Banyak investor yang menanam modal untuk usaha nenas, sehingga buah ini menjadi trend baru di 
pasaran. Tekhnik budidaya nenas semakin baik dan relatif mudah di budidayakan.

Perbanyakan secara vegetatif merupakan suatu cara perbanyakan atau perkembangbiakan tanaman dengan menggunakan bagian-bagian tanaman seperti daun, batang, akar, cabang, ranting, dan umbi untuk mendapatkan individu baru yang sama dengan induknya. Prinsipnya adalah untuk merangsang tunas cabang yang ada dibagian tersebut agar berkembang menjadi tanaman baru tanpa melalui perkawinan (Yefniati, 2000; Yetno, 2001; Girsang, 2003). Tanaman nenas Kingdom : Plantae (tumbuh-tumbuhan), Divisio: Spermatophyta (tumbuhan berbiji), Subdivisio : Angiospermae (berbiji tertutup), Kelas : Monocotiledone, Famili : Bromeliaceae, Genus : Ananas, Spesies Ananas comosus (L) Merr (Raplo, 2003).

Direktorat gizi, Departemen kesehatan RI (1998) dalam Surapti (2001) menyatakan bahwa dalam setiap 100 gram buah nenas mengandung protein 0,4 gram, lemak 0,2 gram, karbohidrat 13,7 gram, kalsium 16,0 gram, fosfor $11,0 \mathrm{mg}$, besi $0,3 \mathrm{mg}$, vitamin A $130 \mathrm{iu}$, vitamin B $0,08 \mathrm{mg}$, vitamin C 24,0 mg dan air 85,3 gram. karena itu buah nenas bisa sebagai penyembuh penyakit sembelit, gangguan saluran kencing, mual-mual, flu, kurang darah, penyakit kulit (gatal-gatal, eksim dan kudis) dapat diobati dengan mengoleskan sari buah nenas. Manfaat buah nenas selain dikonsumsi segar, buah nenas bisa diolah menjadi berbagai makanan dan minuman seperti selai, keripik nenas dan buah dalam sirup. Buah nenas mengandung enzim bromealin, yaitu enzim protease yang dapat menghidrasil protein, protease, atau peptide sehingga dapat digunakan untuk melunakan daging (Hendro dkk, 2008).Kulit buah nenas dapat diolah menjadi sirup atau cairan diektraks untuk pakan ternak dan dapat pula dijadikan selai dan keripik nenas. Daun nenas mempuyai serat panjang yang dapat dimanfaatkan sebagai bahan pakaian (Hidayat, 2008; Wulan, 2009).

Permasalahan yang dihadapi dalam budidaya nenas salah satunya adalah ketersesiaan bibit yang masih terbatas. Sehingga teknik perbanyakan dalam menghasilkan bibit yang berkualitas menjadi hal penting dalam keberhasilan budidaya nenas. Perbanyakan yang umumnya dilakukan adalah melalui penanaman mahkota, dari satu mahkota didapati satu bibit tanaman atau paling banyak dibagi menjadi 4 bagian. Dalam penelitian ini meningkatkan usaha perbanyakan melalui setek daun mahkota. Jadi setiap daun mahkota berpotensi untuk menjadi satu bahan setek. Artinya jika pada satu mahkota terdapat 30 helai daun maka dapat diperoleh 30 setek daun. Menurut Juhardi 1995, teknik perbanyakan vegetatif dengan setek daun nenas adalah metode perbanyakan tanaman dengan menggunakan bagian tanaman yaitu daun nanas itu sendiri yang dipisahkan dari induknya di mana jika ditanam pada kondisi yang menguntungkan untuk beregenerasi akan berkembang menjadi tanaman yang sempurna.

Sumber bahan setek dalam perbanyakan nenas umumnya diambil dari mahkota nenas, anakan dari batang dan tunas yang tumbuh dari pangkal buah. Dari tunas-tunas anakan tersebut hanya menghasilkan satu bahan setek. Melihat morfologi tanaman nenas yang memiliki bakal tunas yang sangat banyak yang selama ini belum termanfaatkan. Tunas-tunas tersebut terdapat pada bahagian dalam kelopak daun dan bahagian dalam setiap helaian daun mahkota. Bakal tunas ini merupakan kekayaan yang bisa dijadikan sumber bahan setek, maka penelitian perbanyakan stek dari tunas daun mahkota menjadi solusi perbanyakan nenas.

Riau memiliki lahan pertanian jenis lahan gambut yang sangat luas. Permasalahan tanah gambut adalah tingkat kemasaman yang sangat tinggi, sehingga perlu upaya peningkatan produktivitas tanah yang intensif, disamping itu dibutuhkan komoditi pertanian yang toleran tumbuh baik dilahan gambut. Tanaman nenas adalah salah satu komoditi yang memiliki toleran yang tinggi terhadap tanah gambut. Lahan gambut di Indonesia seluas 20 juta hektar atau menduduki urutan ke empat dalam katagori lahan gambut terluas di dunia setelah Kanada, Uni Soviet dan Amerika. Riau, merupakan provinsi dengan lahan gambut terluas di Pulau Sumatera yaitu \pm 4,04 juta $\mathrm{Ha}$ atau $56,1 \%$ dari luas total lahan gambut di Sumatera (Wahyunto et.al., 2003).

Salah satu usaha untuk meningkatkan kesuburan lahan gambut ini adalah dengan pemakaian pupuk. Pupuk kotoran kambing merupakan pupuk yang diperoleh dari kotoran kambing yang sudah dihaluskan sehingga mudah dalam pengaplikasiannya, cepat bereaksi dengan tanah sehingga unsur hara dapat langsung diserap oleh tanaman. Pupuk kandang kambing mengandung unsur hara 
$\mathrm{N}, \mathrm{P}, \mathrm{K}, \mathrm{Mg}$ dan $\mathrm{Ca}$ yang diperlukan oleh tanaman.

Perbanyakan tanaman dengan menggunakan setek, pembentukan akar merupakan salah satu kendala, usaha untuk mempercepat pertumbuhan akar pada setek dapat dilakukan dengan memberikan zat pengatur tumbuh. Atonik ymerupakan salah satu ZPT untuk merangsang pertumbuhan akar, Atonik mengandung bahan aktif Naftalena asetat setomida $0,067 \%$, metal- 1 Naftalena setomida $0,013 \%$, indol butirat 0,052 \% dan tiram $4 \%$. Selain itu, Atonik akan memproduksi enzim-enzim dalam mempercepat terjadinya perombakan pati menjadi senyawa-senyawa karbohidrat yang dibutuhkan dalam pembentukan sel-sel baru diantaranya akar dan tunas. Pengaplikasian Atonik juga menekan kematian bibit dilapangan (Tri, 2002).

Upaya teknik perbanyakan tanaman terus dikembangkan, salah satunya penggunaan setek tunas mahkota,di Riau saat ini belum ada hasil penelitian terdahulu tentang perbanyakan nenas Kualu menggunakan tunas daun mahkota, maka dari itu kajian ini perlu dilakukan. Tujuan penelitian ini adalah untuk mendapatkan konsentrasi Atonik dan dosis pupuk kotoran kambing yang tepat untuk perbanyakan tanaman nenas Kualu melalui setek daun mahkota pada tanah gambut.

\section{METODELOGI}

Penelitian ini dilaksanakan di kebun percobaan Fakultas Pertanian Universitas Islam Riau, Kota Pekanbaru. Penelitian ini berjalan selama 6 bulan, dimulai dari bulan Desember 2016 sampai Bulan Mei tahun 2017. Bahan-bahan yang digunakan dalam penelitian adalah setek daun mahkota nenas Kualu, gambut, Pupuk kotoran kambing, Atonik, dolomit, pupuk NPK, Dithane M-45, Decis, polybag $15 \times 20 \mathrm{~cm}$. Alat yang digunakan dalam penelitian adalah cangkul, $\mathrm{pH}$ meter, garu, pisau, pinset, gunting setek, handsprayer, penggaris, gembor, meteran, kamera, timbangan dan alat-alat tulis.

Penelitian ini menggunakan Rancangan Acak Ral (RAL) faktorial, faktor pertama pemberian berbagai konsentrasi Atonik terdiri dari 4 taraf yaitu: 0, 2, 4 dan $6 \mathrm{ml} / \mathrm{l}$. Faktor kedua, pemberian berbagai dosis pupuk kotoran kambing terdiri dari 4 taraf $(0,10,20$ dan $30 \mathrm{~g} /$ tanaman). Diperoleh 16 kombinasi perlakuan dan 3 ulangan sehingga diperoleh 48 plot satuan percobaan. Setiap plot terdapat 4 tanaman, 2 diantaranya dijadikan sebagai sampel, jumlah tanaman seluruhnya adalah 192 tanaman. Data pengamatan di analisis secara statistik. Jika $\mathrm{F}$ hitung lebih besar dari $\mathrm{F}$ tabel dilakukan Uji lanjut beda nyata jujur (BNJ) pada taraf $5 \%$.

Pelaksanaan Penelitian, Pengisian polybag satu minggu sebelum tanam, polybag diisi dengan tanah gambut dan ditambahkan kapur dolomit ini bertujuan untuk menetralkan $\mathrm{pH}$. Satu minggu kemudian pupuk kandang kambing ditambahkan sesuai dengan dosis perlakuan.

Nenas yang digunakan sebagai bahan perbanyakan adalah nenas berasal dari daerah Kualu Kampar. Buah nenas yang sudah masak fisiologi dipanen, daun mahkotanya dilepas dari krop mahkota satu persatu. Satu helai daun mahkota dijadikan satu setek daun. Pemotongan dengan menyertakan sebagian bonggol tempat menempelnya tunas. Potongan setek daun diletakkan pada bak berisi air, agar setek tidak kering. Bahan setek yang ditanam adalah irisan sebagian bonggol yang menyertakan mata tunas dan satu helai daun mahkota.

Pemberian Atonik yaitu dengan menyediakan empat formulasi larutan atonik sesuai konsentrasi perlakuan, kemudian setek direndam kedalam larutan Atonik selama 30 menit lalu kemudian ditanam. Setek daun ditanaman kedalam media pada kedalaman 3 $\mathrm{cm}$ didalam tanah, lalu kemudian setiap polybag disungkup dengan plastic bening dan kedap udara supaya kondisi tetap lembab. Penyiraman dilakukan pada permukaan tanah diluar polybag, sementara didalam polybag dilakukan pengkabutan satu kali satu minggu dengan membuka sungkupnya dan kemudian dipasang kembali. Penempatannya sesuai dengan perlakuan dan disusun berdasarkan lay out. Jarak antara polybag adalah $20 \mathrm{~cm}$ dan 50 $\mathrm{cm}$ antar plot. Pupuk yang digunakan adalah NPK Mutiara 16:16:16. dilakukan sebanyak 2 kali yaitu pada saat tanaman berumur 30 dan 60 hari dengan dosis $3 \mathrm{~g} /$ tanaman. Pengamatan dilakukan terhadap Persentase Setek Hidup (\%), Saat Muncul Tunas (hst), tinggi Tunas (cm), Jumlah Daun Per Tanaman (Helai), Panjang Daun Terpanjang (cm, Lebar Daun (cm). 


\section{HASIL DAN PEMBAHASAN}

\section{Persentase Setek Hidup (\%)}

Lahan gambut merupakan lahan marginal, salah satu usaha untuk meningkatkan kesuburannya adalah dengan pemberian unsur hara, unsur hara bisa besumber dari pupuk anorganik juga pupuk organik. Kalenka dalam Dheka (2015), menyatakan pupuk organik mempunyai beberapa keistimewaan, yaitu dapat memperbaiki sifat fisik, biologi dan kimia pada tanah, mempercepat proses dekomposisi, merangsang jasad nitrifikasi dalam tanah, serta daya menahan air yang tinggi, sehingga unsur hara yang diberikan melalui pupuk organik dapat dalam keadaan tersedia bagi tanaman. Berdasarkan fungsi pupuk organik tersebut, maka diduga akan sangat baik jika diberikan pada tanah gambut.
Pupuk kandang kambing merupakan pupuk yang diperoleh dari kotoran kambing yang sudah dihaluskan sehingga mudah dalam pengaplikasiannya, cepat bereaksi dengan tanah sehingga unsur hara dapat langsung diserap oleh tanaman. Pupuk kandang kambing mengandung unsur hara $\mathrm{N}, \mathrm{P}, \mathrm{K}, \mathrm{Mg}$ dan $\mathrm{Ca}$ yang diperlukan oleh tanaman. Kotoran kambing tidak berpengaruh nyata terhadap persentase tumbuh setek tunas mahkota. Trisno (2011), Pemberian pupuk kandang pada media tanam berarti memperkaya kandungan mikrobia yang bermanfaat bagi tanaman. Berikutnya dikemukakan bahwa pemberian dosis $40 \mathrm{~g}$ - 80 g kotoran kambing memberikan pengaruh yang baik terhadap pertumbuhan tanaman.

Tabel 1. Persentase Tumbuh (\%) Setek Daun Mahkota Nenas Kualu Pada Umur 2 Bulan Setelah Tanam

\begin{tabular}{|c|c|c|c|c|c|}
\hline \multirow{2}{*}{$\begin{array}{c}\text { Pukot } \\
\text { Kambing (g) }\end{array}$} & \multicolumn{4}{|c|}{ Konsentrasi Atonik (ml/l) } & \multirow{2}{*}{ Rerata } \\
\hline & $\mathrm{A} 0(0)$ & A1 (2) & A2 (4) & A3 (6) & \\
\hline K0 (0) & 58.33 & 58.33 & 83.33 & 66.67 & $66.67 \mathrm{ab}$ \\
\hline K1 (10) & 75.00 & 58.33 & 66.67 & 58.33 & $64.58 \mathrm{~b}$ \\
\hline K2 (20) & 75.00 & 83.33 & 75.00 & 83.33 & $79.17 \mathrm{a}$ \\
\hline K3 (30) & 83.33 & 50.00 & 66.67 & 66.67 & $66.67 \mathrm{ab}$ \\
\hline Rerata & 72.92 & 62.50 & 72.92 & 68.75 & \\
\hline $\mathrm{KK}=$ & $18.05 \%$ & $\mathrm{BNJ}$ & 13.86 & & \\
\hline
\end{tabular}

Angka-angka pada kolom dan baris yang diikuti huruf kecil yang sama tidak berbeda nyata menurut uji BNJ taraf 5\%.

Dalam perbanyakan setek masalah pertumbuhan akar merupakan salah satu kendala, dimana usaha untuk mempercepat pertumbuhan akar pada setek dapat dilakukan dengan memberikan zat pengatur tumbuh. Diantara banyak formula yang mengandung ZPT untuk merangsang pembentukan akar adalah atonik, formula ini mengandung bahan aktif Naftalena asetat setomida $0,067 \%$, metal1 Naftalena setomida $0,013 \%$, indol butirat $0,052 \%$ dan tiram $4 \%$. Selain itu, dapat memproduksi enzim-enzim dalam mempercepat terjadinya perombakan pati menjadi senyawa-senyawa karbohidrat yang dibutuhkan dalam rangka pembentukan sel-sel baru diantaranya akar dan tunas. Pengaplikasian atonik juga menekan kematian bibit dilapangan (Tri, 2002).

\section{Saat Muncul Tunas (hari)}

Pemberian Atonik dan pupuk kotoran kambing tidak berpengaruh nyata terhadap saat muncul tunas pertumbuhan setek daun mahkota nenas Kualu kampar. Baik interaksi antara keduanya maupun pengaruh masingmasing perlakuan tersebut.

Tabel 2. Saat Muncul Tunas Setek Daun Mahkota Nenas Kualu Pada Umur 2 Bulan Setelah Tanam

\begin{tabular}{|c|c|c|c|c|c|}
\hline \multirow{2}{*}{$\begin{array}{c}\text { Pupuk kotoran } \\
\text { Kambing (g) }\end{array}$} & \multicolumn{4}{|c|}{ Konsentrasi Atonik (ml/l) } & \multirow{2}{*}{ Rerata } \\
\hline & A0 (0) & A1 (2) & A2 (4) & A3 (6) & \\
\hline K0 (0) & 29.00 & 29.67 & 25.00 & 27.33 & 27.75 \\
\hline K1 (10) & 29.00 & 29.67 & 25.00 & 29.67 & 28.33 \\
\hline K2 (20) & 29.00 & 29.67 & 25.00 & 26.67 & 27.58 \\
\hline K3 (30) & 29.00 & 26.67 & 25.33 & 28.67 & 27.42 \\
\hline Rerata & 29.00 & 28.92 & 25.08 & 28.08 & \\
\hline
\end{tabular}


Setek daun nenas yang berasal dari daun mahkota yang memiliki banyak helaian daun, berpotensi untuk dijadikan bahan setek karena diantara crop daun mahkota terdapat satu mata tunas yang dapat dijadikan cikal bakal individu baru. Sehingga perlakuan yang diberikan tidak mempengaruhi saat muncul tunas yang terbentuk dan tetap tumbuh baik menjadi bibit baru. Umur muncul tunas adalah hanya dipengaruhi oleh kekuatan vigor dan daya adaptasi organ nenas yang digunakan cukup baik, sehingga saat muncul tunas tidak dipengaruhi oleh berbagai dosis pupuk kotoran kambing dan berbagai konsentrasi ZPT Atonik yang diberikan.

Penelitian lain Mardaleni dkk (2017), menggunakan mahkota nenas dipotong memanjang (dibelah menjadi delapan bagian, ini juga ternyata bisa sebagai alternatif untuk mengatasi keterbatasan sumber bibit. Perbedaannya dengan penelitian ini, setiap helaian daun pada daun mahkota nenas terdapat satu mata tunas, yang juga berpotensi sebagai bahan perbanyakan, dimana perlakuan yang diberikan tidak memberikan pengaruh yang signifikan, namun waktu yang diperlukan untuk menumbuhkan tunas baru berkisar dalam 25 - 29 hari. Ini menandakan bahwa, penggunaan tunas daun mahkota dapat dijadikan sebagai bahan setek dalam perbanyakan nenas. Sebelumnya penelitian yang dilakukan oleh Naekman dkk (2010), terhadap setek batang nenas dengan mempelajari pengaruh BAP dan air kelapa untuk mendorong produksi tunas potongan batang nanas GP-1 (Ananas comosus L. Merr) dan percobaan kedua adalah pemberian urea dan asam gibereline untuk peningkatan vigor bibit dilapang. Kedua penelitian menunjukkan bahwa perlakuan taraf konsentrasi BAP dan air kelapa tidak berpengaruh signifikan terhadap produksi tunas. Perlakuan pupuk urea dan giberelin hanya berpengaruh pada peubah lebar daun saat umur 16 minggu setelah kultur.

\section{Tinggi Tanaman $(\mathrm{cm})$}

Interaksi dan pengaruh utama pemberian pupuk kotoran kambing dan berbagai konsentrasi Atonik tidak menunjukan pengaruh yang nyata terhadap tinggi tanaman. Atonik yang mengandung auksin, mampu meningkatkan pembentukan perakaran awal, namun belum mampu menggalakkan pertumbuhan yang berbeda nyata bila dilihat dari pertambahan tinggi tanaman. Pertumbuhan yang siknifikan juga tidak terlihat jika penambahan pupuk kompos kotoran kambing ditambahkan.

Tabel 3. Tinggi Tanaman $(\mathrm{cm})$ pada Umur 4 Bulan

\begin{tabular}{|c|c|c|c|c|c|}
\hline \multirow{2}{*}{$\begin{array}{c}\text { Pupuk kotoran } \\
\text { Kambing (g) }\end{array}$} & \multicolumn{4}{|c|}{ Konsentrasi Atonik (ml/l) } & \multirow{2}{*}{ Rerata } \\
\hline & A0 (0) & A1 (2) & A2 (4) & A3 (6) & \\
\hline K0 (0) & 12.53 & 11.50 & 11.00 & 7.83 & 10.72 \\
\hline K1 (10) & 11.66 & 12.89 & 12.58 & 12.33 & 12.37 \\
\hline K2 (20) & 11.17 & 11.38 & 13.22 & 12.55 & 12.08 \\
\hline K3 (30) & 11.67 & 12.33 & 13.50 & 14.50 & 13.00 \\
\hline Rerata & 11.76 & 12.22 & 12.58 & 11.75 & \\
\hline
\end{tabular}

Tidak ada perbedaan pertumbuhan yang nyata pada bibit yang direndam dalam atonik selama 30 menit. Tidak berpengaruh nyata terhadap tinggi tanaman. Sebelumnya Rugaya dkk. 2012, melihat pengaruh cara aplikasi IBA dengan pengolesan lebih baik dalam menghasilkan jumlah akar primer. Pengaruh konsentrasi IBA terhadap pertumbuhan bibit nenas asal tunas mahkota tidak ditentukan oleh cara aplikasinya. Menggunakan zpt dari IBA 400 ppm mampu meningkatkan jumlah akar primer, lebar daun, dan bobot basah tanaman. Sebelumnya Satria, A. (2011) merendam setek Buah Naga pada larutan atonik dengan konsentrasi $0,0,4,0,8,1,2$, dan 1,6 ml/1 selama
30 menit, memberikan hasil yang hampir sama terhadap keberhasilan pertumbuhan bibit.

Kandungan hormon murni dari golongan sitokinin yaitu BAP direndamkan pada planlet nenas selama 30 menit, maka perbedaan tinggi tanaman dapat terlihat nyata pada penelitian (Dwi dkk 2013), menguji ZPT BAP pada pertumbuhan planlet nenas hasil kultur jaringan. Interaksi antara pemberian BAP dan pengelompokan umur berpengaruh nyata untuk variabel tinggi plantlet dan jumlah daun, pemberian $25 \mathrm{ppm}$ BAP menghasilkan tinggi tanaman paling tinggi berbanding konsentrasi 50 dan $75 \mathrm{ppm}$ BAP. Tanah 
gambut merupakan bahan organik yang didalamnya mengandung unsur nitrogen yang baik untuk pertumbuhan tanaman baru, namun untuk pertumbuhan berikutnya setiap tanaman memerlukan nutrisi yang perlu ditambahkan dari sumber berupa pupuk. Pupuk organik berupa kotoran ternak yang sudah dikomposkan dapat lebih cepat dimanfaatkan oleh bibit nenas.

\section{Jumlah Daun (helai)}

Tidak ada pengaruh interaksi pemberian pupuk kotoran kambing dan ZPT Atonik terhadap jumlah daun bibit nenas asal setek daun mahkota, begitu juga konsentrasi atonik secara tunggal. Namun pupuk kotoran kambing memberikan pengaruh yang nyata, dosis pupuk kotoran kambing $30 \mathrm{~g} / \mathrm{tanaman}$ dapat mempromot pembentukan daun terbanyak bila dibandingkan dengan tanaman yang diberikan dosis yang lebih rendah.

Potensi pembentukan pucuk baru, jumlah daun yang terbentuk lebih dari 10 helai pada umur lima bulan. Jumlah daun lebih sedikit pada tunas asal setek batang dan setek daun (Mardaleni dkk 2017). Menurut Elfiani dkk 2012, terjadi peningkatan bobot daun dengan penambahan jumlah daun pada bibit nenas hasil kultur jaringan yang pada media yang ditambahkan pupuk Nitrogen hingga 1 gram. Unsur hara $\mathrm{N}$ sangat dibutuhkan untuk pertumbuhan vegetatif tanaman terutama untuk pertambahan jumlah daun, tetapi pemberian $\mathrm{N}$ dengan dosis yang lebih tinggi dapat menghambat pertambahan jumlah daun.

Tabel 4. Jumlah Daun Yang Terbentuk Pada Setek Daun Mahkota Pada Umur 5 Bulan

\begin{tabular}{|c|c|c|c|c|c|}
\hline \multirow{2}{*}{$\begin{array}{c}\text { Pupuk kotoran } \\
\text { Kambing (g) }\end{array}$} & \multicolumn{4}{|c|}{ Konsentrasi Atonik (ml/l) } & \multirow{2}{*}{ Rerata } \\
\hline & $\mathrm{A} 0(0)$ & A1 (2) & $\mathrm{A} 2(4)$ & A3 (6) & \\
\hline K0 (0) & 10.33 & 7.67 & 10.00 & 8.67 & $9.17 \mathrm{~b}$ \\
\hline K1 (10) & 10.22 & 11.11 & 10.61 & 10.00 & $10.49 \mathrm{a}$ \\
\hline $\mathrm{K} 2(20)$ & 9.00 & 9.67 & 10.05 & 10.17 & $9.72 \mathrm{~b}$ \\
\hline K3 (30) & 9.66 & 10.00 & 11.00 & 10.33 & $10.25 \mathrm{ab}$ \\
\hline Rerata & 9.80 & 9.61 & 10.42 & 9.79 & \\
\hline $\mathrm{KK}=16.29 \%$ & & $\mathrm{BNJ} \mathrm{K}=1$ & & & \\
\hline
\end{tabular}

Angka-angka pada kolom dan baris yang diikuti huruf kecil yang sama tidak berbeda nyata menurut uji BNJ taraf 5\%
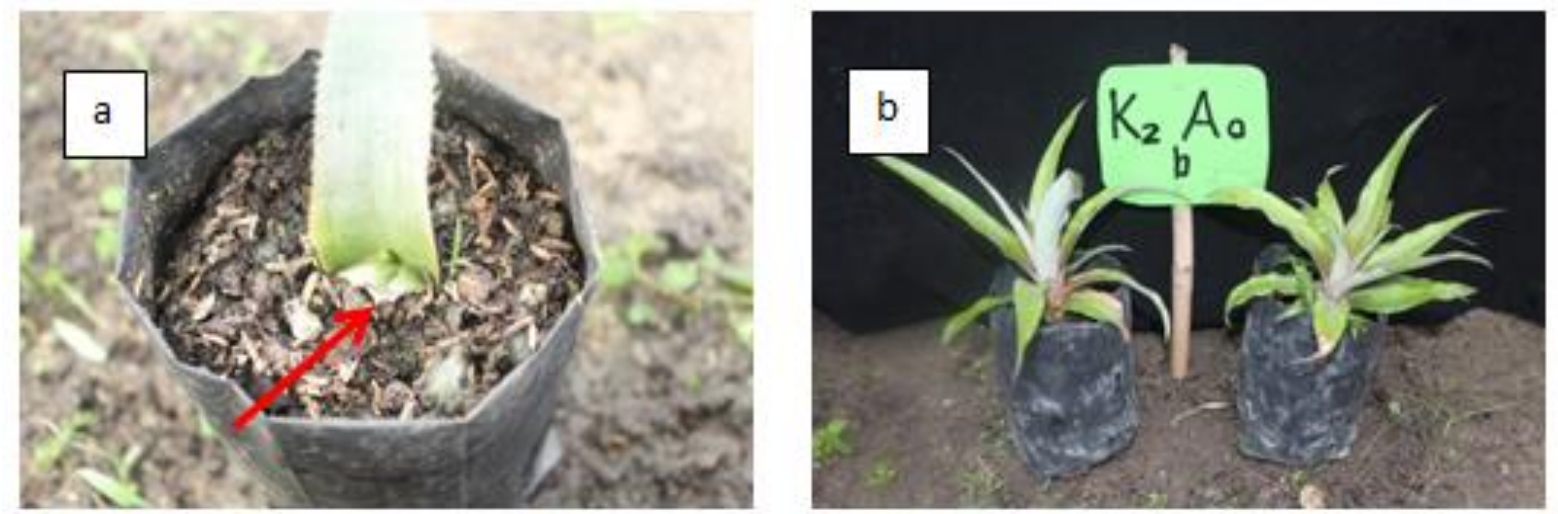

Gambar 1. a. Tunas yang baru terbentuk pada umur 2 minggu setelah tanam

b. Kemandirian bibit setek daun mahkota yang diberikan pupuk kandang kambing 20 g/tanaman pada umur 5 bulan.

\section{Panjang Daun (cm)}

Tidak ada pengaruh interaksi maupun pengaruh utama dari pemberian pupuk kotoran kambing dan konsentrasi ZPT Atonik terhadap panjang daun bibit nenas asal setek daun mahkota yang ditanam pada media gambut. Pertambahan panjang daun bibit nenas Kualu terbentuk dengan ukuran yang dinilai sama berdasarkan analisis statiktik menggunakan rancangan acak lengkap faktorial. Panjang daun bibit nenas pada umur 5 bulan berkisar antara 11,33 sampai $13,67 \mathrm{~cm}$, tidak ada perbedaan yan signifikan antara bibit yang diberikan berbagai dosis pupuk kotoran kambing dan beberapa konsentrasi Atonik yang diujikan. 
Tabel 5. Panjang Daun Setek Mahkota Daun Nenas Pada Umur 5 Bulan

\begin{tabular}{|c|c|c|c|c|c|}
\hline \multirow{2}{*}{$\begin{array}{c}\text { Pupuk kotoran } \\
\text { Kambing (g) }\end{array}$} & \multicolumn{4}{|c|}{ Konsentrasi Atonik (ml/l) } & \multirow{2}{*}{ Rerata } \\
\hline & A0 (0) & A1 (2) & A2 (4) & A3 (6) & \\
\hline K0 (0) & 12.33 & 11.33 & 12.33 & 11.33 & 11.83 \\
\hline K1 (10) & 12.00 & 12.83 & 12.17 & 12.00 & 12.25 \\
\hline K2 (20) & 12.00 & 13.33 & 13.17 & 13.67 & 13.04 \\
\hline $\mathrm{K} 3(30)$ & 11.83 & 13.00 & 13.00 & 12.33 & 12.54 \\
\hline Rerata & 12.04 & 12.63 & 12.67 & 12.33 & \\
\hline $\mathrm{KK}=8.70 \%$ & \multicolumn{4}{|c|}{ BNJ $\mathrm{K}=1.20$} & \\
\hline
\end{tabular}

\section{Lebar Daun (cm)}

Tidak ada pengaruh interaksi pemberian pupuk kotoran kambing dan ZPT Atonik terhadap jumlah daun bibit nenas asal setek daun mahkota. Begitu juga konsentrasi atonik yang diuji. Namun pupuk kotoran kambing memberikan pengaruh yang nyata, pemberian 30 gram per tanaman dapat mempromot pertumbuhan, pembentukan daun lebih lebar bila dibandingkan dengan tanaman yang diberikan dosis yang lebih rendah.

Pertumbuhan vegetatif pada awal pembentukan daun sangat ditentukan oleh ketersediaan unsur hara Nitrogen didalam tanah. Penambahan pupuk organik kompos kotoran kambing pada dosis $30 \mathrm{~g} /$ tanaman dapat memberikan perbedaan pertumbuhan lebar daun bibit nenas. Pada tahap awal pertumbuhan setek hingga umur setek 2 hingga 3 bulan, tunas muda masih memanfaatkan nutrisi yang berasal dari helaian daun yang disertakan pada saat penanaman. Bahkan, hingga umur 5 bulan akhir penelitian sebagian dari daun awal setek ada yang masih hidup bersama daun-daun muda yang baru terbentuk.

Tabel 6. Lebar Daun Setek Daun Mahkota Pada Umur 5 Bulan

\begin{tabular}{lccccc}
\hline Pupuk kotoran & \multicolumn{4}{c}{ Konsentrasi Atonik (m1/l) } & \multirow{2}{*}{ Rerata } \\
\cline { 2 - 4 } Kambing $(\mathrm{g})$ & $\mathrm{A} 0(0)$ & $\mathrm{A} 1(2)$ & $\mathrm{A} 2(4)$ & $\mathrm{A} 3(6)$ & $3.34 \mathrm{~b}$ \\
K0 $(0)$ & 3.07 & 3.50 & 3.40 & 3.40 & $3.38 \mathrm{ab}$ \\
K1 $(10)$ & 3.17 & 3.67 & 3.40 & 3.27 & $3.88 \mathrm{ab}$ \\
K2 $(20)$ & 3.83 & 3.93 & 3.83 & 3.90 & $3.93 \mathrm{a}$ \\
K3 $(30)$ & 3.77 & 4.17 & 3.77 & 4.00 & 3.64 \\
\hline Rerata & 3.46 & 3.82 & 3.60 &
\end{tabular}

Angka-angka pada kolom dan baris yang diikuti huruf kecil yang sama tidak berbeda nyata menurut uji BNJ taraf 5\%

Potongan bonggol mahkota yang diikutsertakan pada setek, dimana awalnya tunas tersebut masih dorman, apabila diberikan perlakuan perendaman pada larutan atonik dapat menggiatkan aktifitas sel dalam tunas meningkat dan induksi pucuk lebih cepat muncul. Sari (2003) mengemukakan bahwa pada batang nanas terdapat tunas dorman pada nodul batang yang jumlahnya mencapai 40 tunas. Dimana tunas tersebut dapat diaktifkan untuk mendapatkan tanaman baru dalam penyediaan bibit tanaman nanas.

Selama proses awal penanaman setek, bakal tunas mendapat asupan nutrisi dari potongan nodul untuk mengaktifkan bakal tunas yang ada diketiak daun mahkota dengan teknik pemotongannya menyertakan bagian bonggol tempat tumbuhnya tunas serta daun mahkota. Jika dilakukan pemotongan, secara fisiologi hormon auksin endogen akan aktif dan bakal tunas dapat dengan mudah berkembang dan menjadi tunas tunas baru.
Sebelum terbentuk akar, tunas mendapat nutrisi dari bagian bonggol yang terikut dan daun mahkota yang masih muda, ditambah dengan kondisi lingkungan yang lembab dengan penyungkupan selama 3 minggu merupakan kunci keberhasilan perbanyakan memalui setek tunas daun mahkota nenas.

Pertumbuhan setek mahkota daun nenas baik pertumbuhannya dengan indikasi penambahan lebar daun, dikemukakan pada hasil penlitian Husniati (2010), dimana Interaksi media tanam pasir + kompos dengan konsentrasi auksin $0.17 \mathrm{ppm}$ memiliki nilai lebar daun tertinggi pada 12 MST hingga 16 MST yaitu sebesar $1.82 \mathrm{~cm}$ (12 MST), $1.92 \mathrm{~cm}$ (14 MST) dan $2.01 \mathrm{~cm}$ (16 MST). Nilai lebar daun rendah jika setek mahkota daun nenas ditanam pada media tanam arang sekam + kompos dengan konsentrasi auksin $0.34 \mathrm{ppm}$ dengan nilai lebar daun hanya $0.99 \mathrm{~cm}(12$ MST), $1.02 \mathrm{~cm}$ (14 MST) dan $1.07 \mathrm{~cm}$ (16 MST). 


\section{KESIMPULAN}

Perbanyakan nenas bersumber dari setek tunas daun mahkota dapat dijadikan salah satu teknik perbanyakan nenas. Setiap bakal calon tunas pada mahota berpotensi sebagai bahan perbanyakan. Persentase tumbuh setek mencapai 83,33\%. Interaksi konsentrasi atonik dan berbagai dosis pupuk kandang kambing tidak menunjukan pengaruh yang signifikan. Pertambahan jumlah daun dan lebar daun sangat dipengaruhi oleh kandungan nutrisi yang diberikan, $30 \mathrm{~g} / \mathrm{tanaman}$ pupuk kandang kambing menunjukan pertambahan jumlah daun dan lebar daun menjadi meningkat dibandingkan tanaman yang diberikan pada dosis yang lebih rendah.

\section{UCAPAN TERIMAKASIH}

Ucapan terimakasih disampaikan kepada Lembaga Penelitian Universitas Islam Riau yang telah mendanai penelitian ini dengan Surat Keputusan Nomor: 63/KONTRAK/LPUIR/2016.

\section{DAFTAR PUSTAKA}

Badan Institut Pertanian Lembang. 1994. Bercocok Tanaman Nenas. Edisi November. Bandung.

Dwi RS.; Sobir. 2013. Pertumbuhan planlet nenas (Ananas comosus L. Merr.) varietas Smooth Cayene hasil kultur invitro pada beberapa konsentrasi BAP dan umur planlet. bul. Agrohort, 1(1);54-61

Elfiani, Aryati V., 2012. Keragaan pertumbuhan bibit nenas (Ananas comosus L. Merr.) hasil kultur jaringan dengan pemberian Giberellin dan pupuk Nitrogen melalui daun. Prosiding seminar dan kongres Nasional sumberdaya genetik, Medan.

Hadiati S., Putu I.N.L., 2008. Petunjuk Teknis Budidaya Nenas. Balai Penelitia

Tanaman Buah Tropika, Solok.

Husniati, K. 2010. Pengaruh Media Tanam Dan Konsentrasi Auksin Terhadap Pertumbuhan Stek Basal Daun Mahkota Tanaman Nenas (Ananas Comosus L. Merr) Cv. Queen. Skripsi Program Studi Pemuliaan Tanaman Dan Teknologi Benih Fakultas Pertanian Institut Pertanian Bogor, Bogor.
Juhardi, D. 1995. Studi Pembiakan Vegetatif Setek Pucuk Shorea selanica BL dengan Menggunakan Zat Pengatur Tumbuh IBA pada Media Campuran Tanah dan Pasir. Skripsi Fakultas Kehutanan Institut Pertanian Bogor, Bogor.

Naibaho, N.; Diniarti D. dan Sobir. 2010. Studi Perbanyakan Bibit Dengan Stek Batang Dan Perbaikan Pertumbuhan Bibit Nenas Gp-1 "Ananas comosus L. Merr" Prosiding 558 Seminar HasilHasil Penelitian Institut Pertanian Bogor, Bogor.

Rosmaina. 2008. Pengaruh Perlakuan BA dan NAA terhadap Pembentukan Akar Nenas (Ananas comosus (L). Merr.) cv. Smooth Cayenne Secara In Vitro of Department of Agrotechnology, UIN SUSKA, Pekanbaru.

Rugayah, I. Anggalia dan Y.G. Cahya. 2012. Pengaru aplikasi dan daya konsentrasi IBA (Indole Butiric Acid) terhadap pertumbuhan bibit nenas (Ananas comosus L. Merr.) asal tunas mahkota. Jurnal Agrotrofika 17(1):75-78. Lampung.

Sari, R. N. 2002. Analisis Keragaman Morfologi dan Kualitas Buah Nenas (Ananas Comocus (L) Merr) Queen Di Tempat Desa Kubang Subang. Skripsi. Depertemen Agronomi Dan Hortikultura, Fakultas Pertanian. Institut Pertanian Bogor, Bogor.

Satria, A. 2011. Pengaruh Beberapa Konsentrasi Atonik Pada Pertumbuhan Setek Buah Naga Berdaging Merah (Hylocereus Costaricensis (Web.) Britton \& Rose). Universitas Andalas, Padang.

Tri, F.S., S. Darmanti, dan B. Raharjo. 2002. Pengaruh Waktu Lama Perendaman dan Konsentrasi Growtone Terhadap Pertubuhan Setek Horizontal Jeruk Manis (Citrus ratikula). Artikel penelitian laboratorium struktur dan fungsi tumbuhanUniversitasDiponegoro. http://eprints.undip.ac.id. Diakses pada 04 Desember 2013.

Wahyunto, S. Ritung, and H. Subagjo. 2003. Map of Peatland Distribution Area and Carbon Content in Sumatra. Wetland International Indonesia Program and Wildlife Habitat Canada (WHC). 
Pengaruh Pemberian Pupuk Kotoran Kambing dan Atonik terhadap Pertumbuhan Setek Daun Mahkota Nenas (Ananas comusus L. Merr) Kualu pada Media Gambut 